\title{
TACTICAL USE OF BIOLOGICAL WEAPONS FOR TERRORIST GOALS
}

\author{
Zlate Dimovski, PhD \\ Full Professor, Faculty of Security, University "St. Clement of Ohrid" - Bitola \\ E-mail: zdimovski@fb.uklo.edu.mk \\ Ice Ilijevski, PhD \\ Assistant Professor, Faculty of Security, University "St. Clement of Ohrid" - Bitola \\ E-mail: iilijevski@fb.uklo.edu.mk \\ Kire Babanoski, PhD \\ Assistant Professor, Faculty of Security, MIT University - Skopje \\ E-mail: kire.babanoski@mit.edu.mk
}

\section{Abstract:}

The bioterrorist attacks are very efficient and deadly because for a short period of time they cause massive civilian casualties, and achieve psychological fear and anxiety among the general population. In order to achieve their goals, some terrorist structures have members who possess good theoretical and practical knowledge as well as technical information from various scientific fields with regard to the most important features of the production and use of biological agents. The use of biological weapons in various deadly attacks committed by terrorist organizations for fulfilling their goals is the main subject of this paper. Firstly, we consider the characteristics of biological agents, including bacteria, viruses and toxins that can be converted into biological weapons suitable for use in terrorist activities, and then we specifically pay attention to the tactical ways of their usage. A detailed research of their properties and tactics of storage, transportation and use for terrorist purposes is necessary to evaluate the current established measures for anti and counter terrorism and propose more effective strategies to prevent future attacks using biological weapons.

Key words: biological weapons, virus, tactics, terrorism, terrorist act.

\section{Introduction}

The biological weapons, given their characteristics and properties, are classified in the group of weapons of mass destruction. The groups of agents that can be used as a biological 


\section{Security}

weapons include viruses, bacteria, rickets, Chlamydia, fungi and toxins from living organisms. Some of them (Anthrax and Ebola) can be genetically modified causing major problems in their detection, identification, diagnosis and treatment itself. The choice of the bio warfare agent (Riedel, 2004) depends on the economic, technical, and financial capabilities of a state or an organization. Smallpox, Ebola, and Marburg virus might be chosen because of their reputation for causing most horrifying effects. Images of doctors, nurses, and law enforcement personnel in full protective gear is likely to cause widespread public distraction and anxiety.

According to some intelligence information, in addition to the great world powers, at least twelve other countries in the world are intensively working on biological weapons development programs. The justification they use usually refers to the alleged defensive purposes of today's biological weapons, i.e. as one of the methods for deterrent from the potential aggressor. The second argument is that they develop methods for protection against the possible use of this type of weapon. The UN inspections - carried out just in 1993 - found that biological weapons had been developed in Iraq since 1985, and in a relatively short period of time, Iraq produced around 8,500 liters of anthrax, approximately 20,000 liters of botulinum toxin- $A$ and over 2,000 liters myth toxins. All these agents were stored and ready for use (Jovanovic and Micevic, 2005: 22). According to the previously obtained data, it is believed that today it is very likely that (in addition to USA, Russia, China) programs for the biological weapons development exist also in North Korea, Taiwan, Iran, India, Egypt, Israel, Cuba, Pakistan, Kazakhstan, etc.

The Convention on the Prohibition of the Development, Production and Stockpiling of Bacteriological (Biological) and Toxin Weapons and on their Destruction, commonly known as the Biological Weapons Convention (BWC) or Biological and Toxin Weapons Convention (BTWC), opened for signature in 1972 entered into force in 1975. The Convention effectively prohibits the development, production, acquisition, transfer, retention, stockpiling and use of biological and toxin weapons. It is seen as a key element of the international community's efforts to address the proliferation of weapons of mass destruction. It was the first multilateral disarmament treaty banning an entire category of weapons, as States Parties to the BWC undertook "never in any circumstances to develop, produce, stockpile or otherwise acquire or retain: microbial or other biological agents, or toxins whatever their origin or method of production, of types and in quantities that have no justification for prophylactic, protective or other peaceful purposes; and weapons, equipment or means of delivery designed to use such agents or toxins for hostile purposes or in armed conflict."

The rapid development of biotechnology enables easier laboratory creation of deadly viruses and bacteria that could easily be abused in a terrorist attack. Their effects could be worse than those of an atomic bomb. The bioengineering is progressing at a rapid pace, and there are many laboratories in the world, which local governments are incapable of regulating and controlling. If in 2002 it took five years to create a genetic sequence of Polio virus, today in a well-equipped laboratory the whole procedure can be completed in just three days. At the same time, with the decrease of the prices of equipment and materials, as a consequence of the global 
economic crisis, hundreds of legal and illegal laboratories emerge around the world. The economic factor stimulates scientists to compete in the production of commercial products that could be placed in the pharmaceutical or food industry. But the lack of control over these laboratories can easily turn them into biological and chemical weapons production facilities.

The use of chemical, biological, radiological and nuclear weapons (Mazzone, 2013: 25) poses a great threat to the international security. So far their use by terrorist groups and/or individuals has not caused mass destruction, but they have had considerable effect on the societies against which they were used. In fact, one of the main motivations behind the use of chemical, biological, radiological and nuclear weapons is precisely the psychological effects on the populations they target. Furthering this point, one may argue that the effect of terrorist use of these weapons is a force multiplier.

The general aim of this article is to illustrate the danger of the possession and use of biological weapons by terrorist organizations in pursuing their ideological goals. For this purpose we briefly explain the characteristics of biological agents, including bacteria, viruses and toxins, which can be converted into biological weapons suitable for use in terrorist activities. Studying the tactics of keeping, transporting and using them for terrorist purposes is necessary for assessing the current anti-counter terrorism measures and proposing more successful strategies for preventing future attacks with biological weapons.

\section{Characteristics of the Biological Weapons}

The types of biological weapons as weapons of mass destruction and disabling people, fauna and flora have some general properties and special features for certain types of agents. Jovic and Savic (2004:125-132) list the following properties that make them insidious weapons:

- Spaciousness and mass destruction, as well as disabling people, plants and animals on the affected territory, but also on a wider and even on intercontinental scale, the spread of an epidemic or a pandemic of dangerous infectious diseases;

- Explosiveness and durability of the spread of infectious diseases or the destruction of plant crops and the maintenance of the consequences in the form of endemic hotspots of infectious diseases;

- A strong psychological effect such as fear, panic and disorientation of the population, due to the emergence and rapid spread of epidemics of infectious diseases with a high mortality rate, as well as because of disabling of the living force for resistance against the aggressor;

- The durability of the atmospheric bio-contamination, the water, the food passing through the source and the direction for the spread of epidemics of infectious diseases;

- The existence of an invisible period of incubation of several days or months, from the onset of the spread of the disease to the occurrence of the signs of the disease, by which the type of the disease would be identified. Incubation (Panovski et al., 2009) is a period with no symptoms of the disease that begins from the moment of entry - the infection of 


\section{Security}

the microbes in the human body - until the onset of the first symptoms. This is a period in which the disease spreads but is not recognized and, as a rule, it is always delayed by taking protective measures.

The biological weapons can be used secretly or covertly, because they are invisible, colorless, odorless and tasteless, which is unnoticeable for human senses and is very difficult to detect and use with instruments, do not cause destruction and can be used from a distance. The discovery of a biological attack is usually possible only after the emergence of the characteristic symptoms within days, weeks or months of the attack. This means that biological agents do not cause immediate (direct, immediate) effects, as is the case with conventional weapons. In this case, the effects are delayed as measured in days (when using microorganisms), and very rarely in hours (when toxins are used). As living matter, biological agents are the only weapon that has the ability to reproduce during and after the attack, and at the same time it spontaneously spreads beyond the primary target. This weapon is spread through contaminated media, water, air, food and soil, but also through infected individuals who transmit microorganisms to disease-causing healthy people, whether they are reconvalescents, microbial carriers or corpses.

According to the international conventions, biological weapons are microorganisms and other biological agents and toxins, regardless of their origin or mode of production and whose possession is not intended for a prophylactic, preventive or other peaceful purpose, as well as weapons and equipment and other means and ways of disseminating agents because of hostile intentions or use in military conflicts. Biological weapons (Riedel, 2004) are unique in their invisibility and their delayed effects. These factors allow those who use them to inculcate fear and cause confusion among their victims and to escape undetected. A bio warfare attack would not only cause sickness and death in a large number but would also aim to create fear, panic, and paralyzing uncertainty. Its goal is disruption of social and economic activity, the breakdown of government authority, and the impairment of military responses.

The main feature of the biological weapons is that it cannot be used for defense purposes (Jovanovic and Micevic, 2005: 19-21). Its production is much cheaper than the production of conventional or nuclear weapons. For example, according to some US sources for achieving lethal effects of an unprotected human population per square kilometer for conventional weapons, it is necessary to invest around $\$ 2,000$, for a nuclear roughly $\$ 800$, for chemical (classic poisoning) $\$ 600$, while for biological weapons it is necessary only invested $\$ 1$ per square kilometer. The US Centre for Disease Control categorizes the following as Category A agents, posing a risk to national security:

- Tularemia or "rabbit fever" - Highly infectious and life-threatening,

- Anthrax - Non-contagious disease. Notably used by persons unknown in a series of mail attacks in 2001,

- Smallpox - Currently only existing in laboratory cultures, but would be a deadly weapon if released once again,

- Botulinum toxin - A highly toxic substance that is readily available, due to its use in "botox" cosmetic procedures, 
- Bubonic plague - The disease that caused the Black Death in Medieval Europe and with a long history of use as a biological warfare agent,

- Viral hemorrhagic fevers - Such as Ebola.

The biological agents are produced in dedicated military, but also in very cheap laboratories that often resemble pharmaceutical, chemical, medical or food facilities. In addition, such facilities (as well as the micro-organisms) may often have a dual purpose. For instance, vaccines, numerous antibiotics and other pharmaceutical preparations can be legally produced. These laboratories are well masked and secured by the eventual finding and identifying their true production. A good example is the Sudanese pharmaceutical industry "Shifa", which was located in the northern suburb of Khartoum. There, with the help of scientists from Iraq and the financial support of Osama Bin Laden, there was a major program based on the production of biological and chemical agents for the needs of the ex-Islamic organizations, above all al Qaeda. The initial components for the production of biological and chemical agents according to the same source were purchased on the "black market" in the former USSR. Assessing the potential danger from the Shifa pharmaceutical facilities, President Clinton ordered destruction of the complex on August 20, 1998. According to US sources, al-Qaeda had two more facilities for production of biologically and possibly chemical agents located near Kust and Jalalabad in Afghanistan.

Another very important feature of biological weapons is their hidden mode of preparation, especially if its bioterrorist actions are at stake. Namely, the bioterrorism activity is very difficult to establish and prove if there is no convincing epidemiological or material evidence. Therefore, a well-trained individual or group that knows the toxicological, epidemiological and environmental characteristics of a region can cause diseases of smaller or larger proportions that are difficult to distinguish from naturally occurring epidemics.

The key factors (Eitzen, 1997: 438) that make a biological pathogen or toxin suitable for a largescale bio warfare attack include: (a) availability or ease of production in sufficient quantity; (b) the ability to cause either lethal or incapacitating effects in humans at doses that are achievable and deliverable; (c) appropriate particle size in aerosol; (d) ease of dissemination; (e) stability (while maintaining virulence) after production in storage, weapons, and the environment; and ( $f$ ) susceptibility of intended victims with nonsusceptibility of friendly forces.

During the past 20 years, we have witnessed revolutionary breakthroughs at the molecular level, above all in the field of genetic engineering, which allows identification and decoding of certain segments in the DNA chain. By applying the molecular biological technique, it is possible to manipulate the segments, that is, the sequences of the DNA molecules, thus obtaining organisms that have altered characteristics. According to the analysis of many analysts, the danger is that with the application of genetic engineering, a completely new generation of biological agents will be obtained. With manipulations in genetic engineering, many biological agents can increase the vitality, toxicity, and more than 100 times the resistance of external influences such as heating and UV radiation will increase. The biotech revolution (Jovanovic and Micevic, 2005: 25-30) has also allowed for greater stability in toxins, making it easier to spread them in a form of aerosols; also it is easier to produce so called "Himeric toxins", which are a combination of two 


\section{Security}

completely different molecules of toxins, Ricine and Diphtheria toxin. Such combinations have great penetrating power in the organisms and a great killer force. By biotechnological procedures, the antigenic composition of a large array of microorganisms can be successfully altered, and thus existing vaccines (anthrax vaccines) become ineffective. In 1984, the Soviet Union began developing a secret program (project Camp fire) in the field of genetic engineering, in order to obtain bacteria from plague and anthrax that will be resistant to many well-known antibiotics and vaccines. Sergey Popov has been one of the top biological weapons experts in the former USSR for more than twenty years, and in the early 1990s he immigrated to the US (www.pbs.org/ wgbh/nova/bioteror). According to him, the former USSR developed several important programs related to the application of biotechnological methods (genetic engineering method) with the intention of modifying a large number of biological agents. Popov was engaged in the method of artificial synthesis in highly pathogenic viruses and bacteria which in natural form do not exist in the external environment. One of Popov's activities was the genetic modification of the Legionella species bacteria in order to obtain a bacterial species that causes severe diseases in the nervous system, most often with a fatal end, followed by symptoms that are very similar to the symptoms of multiple sclerosis. These symptoms of the disease appeared several days after the "complete healing" of bacterial Legionella infection. Explaining the super-secret project called Hunter, Popov presents the possibility of forming completely new hybrid viruses from already existing and known. Within the Hunter project, there have been several successful attempts at hybrid combinations between bacteria and viruses. According to Popov's allegations, the best results were achieved in the combination of bacteria from the plague and the encephalomyelitis virus, major measles and Ebola. With genetic manipulation, a complete virus was inserted into the bacteria of the plague, whereby the virus was stationary. When there is an infection in humans from a bacterial plague, symptoms of plague disease occur. The patients are treated with antibiotic therapy, which usually yields good results. At the moment when the bacteria is destroyed the virus that is immune to antibiotics arises in the organism, so the effect of the encephalomyelitis, measles and Ebola virus on living organisms is most often fatal (deadly).

Despite the numerous advantages of using biological weapons for terrorist purposes, there are certain limitations and weaknesses that make terrorist organizations not to use them very often. According to Eitzen (1997: 443) these are:

- The danger that biological agents can also affect the health of the aggressor forces,

- The dependence on prevailing winds and other weather conditions on effective dispersion,

- The effects of temperature, sunlight, and desiccation on the survivability of some infectious organisms,

- The environmental persistence of some agents, such as spore-forming anthrax bacteria, which can make an area uninhabitable for long periods,

- The possibility that secondary aerosols of the agent will be generated as the aggressor moves through an area already attacked,

- The unpredictability of morbidity secondary to a biological attack, since casualties (including civilians) will be related to the quantity and the manner of exposure, 
- The relatively long incubation period for many agents, a factor that may limit their tactical usefulness,

- The public's aversion to the use of biological warfare agents.

\section{Tactics of Conducting Bio-Terrorist Attacks}

Intimately linked to the threat-value of these weapons is the view, somewhat widespread, that terrorists may seek chemical, biological, radiological and nuclear weapons because traditional methods may no longer be psychologically "effective" (Center for Counter Proliferation Research, 2002: 6). While it may seem obvious that different terrorist groups may seek to attack different targets based upon their underlying ideologies or beliefs, this is an important point with respect to the desire to propagate chemical, biological, radiological and nuclear terrorism. Since target selection varies, and since particular technologies and expertise may be more available, groups may opt to purchase or develop one weapon type over another. For example, chemical weapons will generally have less of an effect on physical targets, such as buildings, than a nuclear device. Similarly, a contagious biological agent that targets agriculture could in theory impose a greater economic cost than a chemical attack. Target selection is a key variable: a group may not seek to acquire simply what is the easiest to acquire, but rather what they assess would be most effective against a specific target or target set.

The use of biological weapons in terrorist attacks has tremendous advantages over the other types of weapons, because it is simple to operate, easily produced and is much cheaper than other types of weapons. There are also huge opportunities for spreading toxins on large surfaces and very difficult to detect (no color, taste, smell). When used, a large number of patients appear in a short period of time and the most important advantage is the panic that appears among the population when it becomes known that infectious diseases are released.

However, despite these advantages and good toxicological and infectious characteristics in order for biological agents to be used as weapons, it is necessary to fulfill certain conditions. The ability of biological agents to cross into aerosols is certainly the most important requirement that each agent must satisfy to be used as a biological or terrorist weapon (Saulic, 1966: 44). The aerosols are actually solid or liquid particles in the form of dust or mist that float in the air or can be carried by the flow of various types of inspectors. It is well known that poisoning through the respiratory organs is the most effective way of poisoning.

The agent that pretends to be used as a weapon must be soluble in liquids, especially in water, in order to contaminate water and other drinks. The biological agent should be without color, odor and taste. These are very important conditions that must be met when contaminating foodstuffs intended for humans and animals. The production of agents should be cheap and in many cases this condition is met. Namely, for their industrial and poly-industrial production, expensive means and devices of modern technology do not require. Terrorist structures or countries that support them can produce in improvised laboratories or in the production facilities of the food and pharmaceutical industry. The substances used in the production of agents are widely used 


\section{Security}

in these industries and would not cause any suspicious warnings or caution to the competent structures. Detailed information on the method of production of agents can be easily found in open and all available literature, on search engines, etc. Literary information is often so detailed and illustrative that some anti-terrorist experts call it a true guide to bioterrorism actions.

Possession of nuclear, biological, radiological and nuclear weapons equals use (Center for Counter proliferation Research, 2002: 6). The issue of deterring chemical, biological, radiological and nuclear terrorism is closely linked to group motivations. It is a near-universal opinion that deterring the use of these weapons by terrorist who have acquired it will be extremely difficult. Most conclude that acquisition of such weapons generally will lead to attempted use. A more recent, and oft-cited supposition is that had al-Qaeda had such weapons at its disposal, they would have sought to employ them. And with what many view as the most dangerous terrorist groups in the chemical, biological, radiological and nuclear context "religious/millenarian groups that seek to inflict mass casualties on their enemies" preventing acquisition may be equally problematic.

The tactics of bioterrorism include the ways in which biological weapons are used, its characteristics, specificities, modes of use in bioterrorist attacks, but also the means of defense against such weapons. With the exception of the delayed action of some war poisons, from the moment of action to the first symptoms, this weapon has a delayed effect (incubation time), and bioterrorism can be said to be one of the most quiet forms of terrorism, at least in the moments of the terrorist act. The tactic of use (Milic, 2005: 15) requires familiarity with the characteristics of the weapon, such as pathogenicity, path of transmission, resistance to antibiotics, resistance to environmental factors, etc.

According to Wiener and Barrett (1986: 508-509), the indications of a possible bio warfare attack are the following:

- A disease entity that is unusual or that does not occur naturally in a given geographic area, or combinations of unusual disease entities in the same patient populations,

- Multiple disease entities in the same patients, indicating that mixed agents have been used in the attack,

- Large numbers of both military and civilian casualties when such populations inhabit the same area,

- Data suggesting a massive point-source outbreak,

- Apparent aerosol route of infection,

- High morbidity and mortality relative to the number of personnel at risk,

- Illness limited to fairly localized or circumscribed geographical areas,

- Low attack rates in personnel who work in areas with filtered air supplies or closed ventilation systems,

- Sentinel dead animals of multiple species,

- Absence of a competent natural vector in the area of outbreak (for a biological agent that is vector-borne in nature).

The success and the result of the attack depends on the area in which the attack is carried out - whether it is closed or open space and from the meteorological parameters (temperature, 
humidity, etc.). The equipment and accessories for the use of biological agents are widely available and so diverse that it is difficult to specify or define the possibilities for use. To a large extent, the choice of equipment and means of using biological weapons depends on the imagination of the terrorist minds. The equipment and accessories can only be divided according to the manner of use of biological agents (Jovanovic and Micevic, 2005: 51-52):

- Biological weapons - ammunition,

- Equipment for contamination of water and food,

- Equipment for the examination of agents,

- Offensive agents for the use of biological agents - devices,

- Equipment for the use of agents against individuals or smaller groups.

The biological weapons are usually in the form of containers or tape and they can be launched or placed in place and activated at a specific time, only munitions with a strong heat or explosion are not used, because the agents are sensitive to high temperatures.

From a terrorist point of view, the most interesting places to attack are underground railways, underground passages, closed sports and cultural facilities with ventilation, large shopping centers, large buildings with special ventilation, etc. (Jovic and Savic, 2004: 215). Underground railways are particularly suitable for contamination, because there is a semi-closed system and because there is increased airflow that is in favor of improving dissemination (socalled clipped way of inquiring). Such amenities also apply to closed-type objects in terms of air circulation, especially in those objects where it is not possible to open windows, and thus represent an excellent target for bioterrorists. A major problem is the inability to predict which new pathogen could be used by terrorists, and it is therefore of particular importance to coordinate the readiness to react to a bioterrorist attack with the surveillance of contagious diseases and activities for an effective response to the attack.

The diversity of biological weapons and the problems of forecasting the way this weapon would be used set the basic problems in detecting, diagnosing and responding to terrorist threats (Milic, 2005: 17). This weapon is especially dangerous because it can be used in undercover attacks. Secret release of agents in public places due to the incubation period has delayed the action of humans. For example, the first victims may be identified only by medical teams outside the scene of the attack. The first symptoms in the victims refer to a particular type of disease, and the gradual manifestation of other symptoms leads to the establishment of an accurate diagnosis that indicates a certain infection. And during that time, medical teams should specify that an attack has been carried out, to detect the agent, and to prevent new victims. The problem of rapid and proper diagnosis is particularly pronounced when agents are transmitted from person to person. The contamination of water and food (Jovanovic and Micevic, 2005: 60-63) can be carried out with liquid or solid biological agents. The equipment used for this type of contamination does not have to meet any specific conditions. Here one can use glass or plastic packaging for chemicals such as small bottles, ampoules or other dishes. Such packages can simply be opened and the contents to be poured into water or food, and may also be equipped with a time starter. Certain types of biological agents may be in the form of tablets, capsules or microcapsules. 
There are great opportunities in the use of biological agents for testing. By inquiring, the air, water, land, people and all the equipment they use can be contaminated. Various pumps, sprinklers, airborne pressure or gas dispensers and all kinds of sprayers used in agriculture and other industries can be used as equipment, and there are quite a lot of them. Especially dangerous spraying is offered by sports jets on small sports airports and are very often used, and they have very poor security control and supervision. The offensive agents for the use of biological weapons can be made from any container in which the agent can be placed and can be easily opened and interrogated in the air and on the ground. In modern conditions, attempts to use biological weapons should be anticipated from assets that do not attract any attention to detecting and border control services. In terms of contamination of individual or small groups, the most commonly used is the contamination of food and water or the contamination of objects that the victim would use. Containing missiles in the form of small arrows, injections, needles (Bulgarian umbrella) and other means that can penetrate the body of the victim and which can carry on themselves biological agents and toxins can be used from equipment.

It is also necessary to point out an alternative method of contamination or the so-called Vector transmission. Biological agents can also be spread through insects, rodents, birds and other animal organisms called vectors. This kind of organisms - vectors can transmit a large number of serious infectious diseases in humans without having consequences for the perpetrator. Assumptions suggest that this kind of contamination could be used by fundamentalist terrorist groups. The latest scientific knowledge suggests that a man could play the role of a vector very well. Suicide action by extreme Islamists in the future instead of explosives could be performed with a suicide bomber who would be voluntarily infected with a highly virulent agent. Such people with their "normal" physiological activities (coughing, spitting, etc.) in a place where there is a greater presence of people, shopping centers, gyms, public transport, etc. can cause large-scale infections.

Biological weapons may, in fact, be much more effective if used against unsuspecting, un protected, and nonimmune civilian populations than against a fast-moving military organization (Zilinskas, 1990). This was certainly true when the Japanese attempted to use biological weapons against Chinese and Soviet troops in World War II. The objectives of a terrorist group may not be typical military objectives; therefore, biological weapons may be better suited to their purposes.

\section{Countering Bioterrorism}

The varying goals and objectives of terrorist organizations throughout the world require different means of mitigation and response to terrorist attacks (Mazzone, 2013: 29). We must continue to evaluate the causes of and responses to terrorist attacks in order to more fully develop the means to respond effectively. The international community must work together to expand its resources to address the threat of terrorism. Predicting and successfully mitigating terrorist attacks is not always possible. As such, legal sanctions against states and groups that sponsor terrorism will certainly assist in this effort. 
Despite a variety of threats that is overwhelming with regards to the number of microbes with pathogenic potential current biodefence efforts remain focused on a tiny proportion of biological threats. In fact, governments have responded to the threat of bioterrorism by the creation of lists that aim to protect society by restricting access to certain microbes and toxins and creating legal tools for the prosecution of individuals on the basis of possession alone (Casadevall and Relman, 2010). Furthermore, such lists have been used to prioritize the development of countermeasures such as increased vigilance, detection devices, diagnostics, vaccines, drugs and therapeutic immunoglobulins. In general, microbial threat lists have been designed by creating algorithms that attempt to identify the most dangerous types of microbes. Although such algorithms are not in the public domain some hint of the types of considerations taken into account in the generation of such lists can be found in an article authored by scientists from the Center of Diseases of Control (Atlanta, GA) (Rotz and Associates, 2002), the institution responsible for the administering the Select Agent and toxins regulations. It is noteworthy that their risk matrix analysis for assessing the public health impact of potential biological terrorism agents included such diverse criteria as mortality, need for hospitalization, likelihood for dissemination, availability of countermeasures and public perception. The last parameter is interesting since public recognition of a known danger such as anthrax spores is far more likely to cause panic and societal disruption than less wellknown threats (Casadevall, 2012). The US Public Health Security and Bioterrorism Preparedness and Response Act of 2002 (BTA) identifies the most dangerous biological assets that can be used as weapons and instructed the Ministry of National Defence to take additional security measures in laboratories that process this program. This act also predicted the United States to provide technical assistance to countries that want to increase the level of security in laboratories in their state or public institutions, which is a challenge and a need for any country.

The threat of bioterrorism across all countries in the world is real and rising. The first argument concerns the low cost of production and the proliferation of biological weapons, which in the future will be increasingly cheaper and more accessible. The second argument is based on the effectiveness of this type of weapon against other hand-made explosive devices. The third is that bioterrorists encounter fewer difficulties than those who want to use nuclear weapons. On the basis of such arguments, cooperation at the local and national level is urgent, as well as the creation of national strategies to combat bioterrorism.

The counterterrorism experts have long warned that global terrorist structures might use some kind of virus and other dangerous infectious diseases in the eventual biological weapons attack. In 2001, after the invasion of Afghanistan, US soldiers in al-Qaeda training camps found biological weapons manuals. In 2005, however, the French Interpol branch in Lyon opened an office through which police and health experts would exchange information on possible attacks. Interpol also launched a training program for special police forces in 2006 that should prevent possible biological weapons attacks and from there point out that many countries in the world still do not have any legal legislation that would allow the authorities to control the transport of substances and biological agents from which biological weapons could be created. Such activities must be classified as crimes without prejudice to the development of science, but those who wish 
to abuse scientific achievements must be prevented.

In 2010 UK Office for Security and Counter Terrorism in the Home Office has published the Strategy for Countering Chemical, Biological, Radiological and Nuclear Terrorism. Its objectives cover issues relating primarily to three of the key work streams: Pursue, Protect and Prepare:

1. Objective: stop terrorists from carrying out an attack (Pursue),

2.0bjective: deny terrorist access to chemical, biological, radiological and nuclear materials (Protect),

3.0bjective: respond promptly and effectively to a chemical, biological, radiological and nuclear attack and recover as quickly as possible from its impact (Prepare).

According to the Strategy, significant progress has been made in developing capabilities to deal with terrorist-related incidents involving these kinds of materials but challenges remain. Given the complexity of the chemical, biological, radiological and nuclear threat and its probable evolution we need a shared understanding of future objectives and priorities; we also need to create a broad community, in and outside Government, in every country in the world, to ensure those objectives can be met.

\section{Conclusion}

The end of the Cold War contributed to a significant reduction in political and military tensions between the two largest military blocks that until then had extensively competed in the creation of all sophisticated weapons. But finishing their match did not mean the end of the creation of new types of weapons. Since that moment, more frequent regional, national and religious conflicts have started, which require a large amount of weapons. This situation, among other things, has affected the increased production, procurement and possession of chemical, biological, radiological and nuclear weapons in many countries.

The great progress in bacteriology and genetics offers great potential and benefits for medicine, but at the same time poses a danger to humanity. In order to achieve a goal or ideal of the terrorists, it is theirs whether people and members of the security forces will be killed or disabled, for them the priority is to be full and comprehensive, to cause fear, unrest and chaos. This does not require extensive destruction and the use of traditional explosives and so on. The new danger facing the world is bioterrorism. In terms of other types of armament, biological weapons have significant advantages because it is invisible to the naked eye, very quietly, its use does not contribute to material devastation, and in most cases the consequences are extremely deadly. Given its efficiency, it is absolutely unnecessary to produce, maintain, and store in large quantities biological agents, which makes them convenient, easier and more efficient for hiding.

Nowadays the possibility of biological weapons being used in open international conflicts is relatively small. However, the use of this weapon for terrorist purposes by individuals, religious sects, and extremist groups represents a real and growing danger. The risk of using biological agents as terrorist assets has increased dramatically because there are many institutional and non-institutional laboratories and in whose work there is no good insight and control by the 
competent authorized and expert institutions of the system, the relatively easy production of many biological agents which is a privilege for terrorist entities, as well as free access to scientific information via the Internet and expert open literature.

It can be concluded that a new phase in the development of biological weapons begins, which will be recognizable by two characteristics: Abuses in the legal scientific research sector, in order to obtain large financial incomes, regardless of which would be misused the scientific capacities, and strengthening the defense capabilities against weapons of mass destruction, above all, of the great powers, for reasons that already have an image of the potential danger that they are lurking and their environment.

\section{References}

1. Casadevall, A. and Relman, D. A. (2010) "Microbial threat lists: obstacles in the quest for biosecurity?" in: Nat Rev Microbiol, 8, pp. 149-154 https://www.ncbi.nlm.nih.gov/ pubmed/20065941 (visited on 08.07.2017).

2. Casadevall, A. (2012) "The future of biological warfare" in: Microb Biotechnol, 5(5), pp. 584587 https://www.ncbi.nlm.nih.gov/pmc/articles/PMC3815869/ (visited on 26.06.2017).

3. Center for Counter Proliferation Research (2002) Chemical, Biological, Radiological, and Nuclear Terrorism: The Threat According to the Current Unclassified Literature, Washington DC: National Defense University.

4. Eitzen, E. (1997) "Chapter 20 - Use of Biological Weapons" in Sidell, F. R., Takafuji, E.T., Franz, D. R. (eds.) Medical Aspects of Chemical and Biological Warfare. Washington, DC: Office of the Surgeon General, Borden Institute, Walter Reed Army Medical Center pp. 437-450 http://www.au.af.mil/au/awc/awcgate/medaspec/Ch-20electrv699.pdf (visited on 24.05.2017).

5. Mazzone, A. (2013) "The Use of CBRN Weapons by Non-State Terrorists" in: Global Security Studies. Volume 4, Issue 4, pp. 23-30. http://globalsecuritystudies.com/Mazzone\%20 CBRN-AG.pdf (visited 21.05.2017)

6. Rotz, L. D., Khan, A. S., Lillibridge, S. R., Ostroff, S. M., Hughes, J. M. (2002) "Public health assessment of potential biological terrorism agents" in: Emerg Infect Dis., 8, pp. 225-230 https://www.ncbi.nlm.nih.gov/pmc/articles/PMC2732458/ (visited on 23.03.2017).

7. Riedel, S. (2004) "Biological warfare and bioterrorism: a historical review" in: Proc (Bayl Univ Med Cent). 17 (4) pp. 400-406. https://www.ncbi.nlm.nih.gov/pmc/articles/ PMC1200679/ (visited on 15.07.2017).

8. United Kingdom's Office for Security and Counter Terrorism (2010) The United Kingdom's Strategy for Countering Chemical, Biological, Radiological and Nuclear (CBRN) Terrorism. London: Home Office.

9. Wiener, S. L. and Barrett, J. (1986) "Biological warfare defense" in: Trauma Management for Civilian and Military Physicians, Philadelphia: WB Saunders. 
10. Zilinskas, R. A. (1990) "Terrorism and biological weapons: Inevitable alliance?" in: Perspect Biol Med., 1990, 34 (1), pp. 44-72 https://www.ncbi.nlm.nih.gov/pubmed/2274404 (visited on 25.05.2017).

11. Јовановић, Ђ. Мичевић, М. (2005) Биолошки тероризам - превентивно деловање и заштита, Институт безбедности, Београд.

12. Јовић, Р. Савић, А. (2004) Биотероризам, биолошки рат, биолошко оружје. Институт за политичке студије, Београд.

13. Милић, Д. (2005) Биотероризам и употреба биолошког оружја, Ревија за безбедност, Београд: Центар за безбедносне студије.

14. Пановски, H. et. al. (2009) Медицинска микробиологија - општ дел. Скопје: Медицински факултет.

15. Шаулић, М. (1966) Нуклеарно, хемиско и биолошко оружје и заштита. Београд. 